\title{
History of Women in Neurosurgery (WINS)
}

\author{
Alia Hdeib, MD, ${ }^{1}$ Theresa Elder, MD, ${ }^{1}$ Daria Krivosheya, MD, ${ }^{2}$ Disep I. Ojukwu, MD, MBA, MPH, ${ }^{3}$ \\ Olindi Wijesekera, MD, MS, ${ }^{1}$ Dana Defta, MD, ${ }^{1}$ Sharona Ben-Haim, MD, ${ }^{4}$ and \\ Deborah L. Benzil, MD²
}

1 University Hospitals, Case Western Reserve University, Cleveland, Ohio; ${ }^{2}$ Department of Neurosurgery, Cleveland Clinic Foundation, Cleveland, Ohio; ${ }^{3}$ St. George's University School of Medicine, St. George, Grenada; and “University of California, San Diego, California

\begin{abstract}
In 2020, the Women in Neurosurgery (WINS) organization, a joint section of the AANS and Congress of Neurological Surgeons, celebrated 30 years since its inception. In this paper, the authors explore the history of WINS from its beginnings through its evolution over the past three decades. The achievements of the group are highlighted, as well as the broader achievements of the women in the neurosurgical community over this time period.
\end{abstract}

https://thejns.org/doi/abs/10.3171/2020.12.FOCUS20944

KEYWORDS Women in Neurosurgery; WINS; neurosurgery history; women neurosurgeons

$\mathrm{W}$ OMEN in Neurosurgery (WINS), a joint section of the American Association of Neurological Surgeons (AANS)/Congress of Neurological Surgeons (CNS), celebrated its 30th anniversary in 2020. Here, we detail the history of WINS from its inception 30 years ago through three decades of achievements of the organization and its members in the neurosurgical community.

\section{From the Beginning Through the First Decade of WINS}

WINS celebrated its 30th anniversary in 2020, and while room for growth remains, remarkable progress has been made toward accomplishing the goals WINS initially set three decades ago. It was not until 1960 that the first woman became board certified in neurosurgery in the US. ${ }^{1}$ While the number of female medical school applicants increased in the 1970s, and has consistently surpassed male applicants since 1995, the number of women applying to surgical specialties such as neurosurgery has risen at a slower pace. ${ }^{2,3}$ At the time of the conception of WINS in 1989, there were only 23 board-certified female neurosurgeons, only $7 \%$ of neurosurgery residents were female, and only $0.2 \%$ of female residency applicants pursued neurosurgery as their specialty. ${ }^{4}$ At this time, almost one-third of neurosurgical residencies had yet to graduate a woman from their training programs, and only 13 had graduated more than 1 woman. ${ }^{5}$

Although many hurdles that women faced in neuro- surgery at this time were a reflection of barriers within society, the stagnant number of female applicants threatened the small specialty's workforce pipeline, especially given the increasing proportion of female medical students. ${ }^{5}$ Many factors were recognized as contributing to this disparity. For one, the lack of female representation in academic medicine fueled the downstream perception of gender inequality, raising particular concerns regarding the feasibility of achieving academic promotion, leadership positions, and equal compensation. Within organized neurosurgery, no female neurosurgeon had ever held a high-level position as a leader in our societies. No more than 2 women had ever simultaneously been members of The Society of Neurological Surgeons (SNS) until 2007.6,7 No formal or informal networking existed, limiting students' exposure to female mentors within the specialty. ${ }^{8}$ Issues surrounding gender disparity and unconscious bias went unacknowledged.

The 1989 AANS Annual Meeting in Atlanta, Georgia, marked the beginning of a movement for change (Fig. 1). A total of 3 women were in attendance at a luncheon session for residents. They were surprised to see another female neurosurgeon for the first time at the meeting and agreed to meet at the end of the day to reconnect. These 3 women-Drs. Deborah Benzil, Karin Muraszko, and Gail Rosseau-invited any women they encountered to meet later that evening. Nearly a dozen women gathered in the hotel restaurant and connected for the first time, committing to transforming the future for women in neurosurgery.

ABBREVIATIONS AANS = American Association of Neurological Surgeons; ABNS = American Board of Neurological Surgery; CNS = Congress of Neurological Surgeons; CSNS = Council of State Neurological Societies; SNS = Society of Neurological Surgeons; WINS = Women in Neurosurgery.

SUBMITTED October 31, 2020. ACCEPTED December 22, 2020.

INCLUDE WHEN CITING DOI: 10.3171/2020.12.FOCUS20944. 


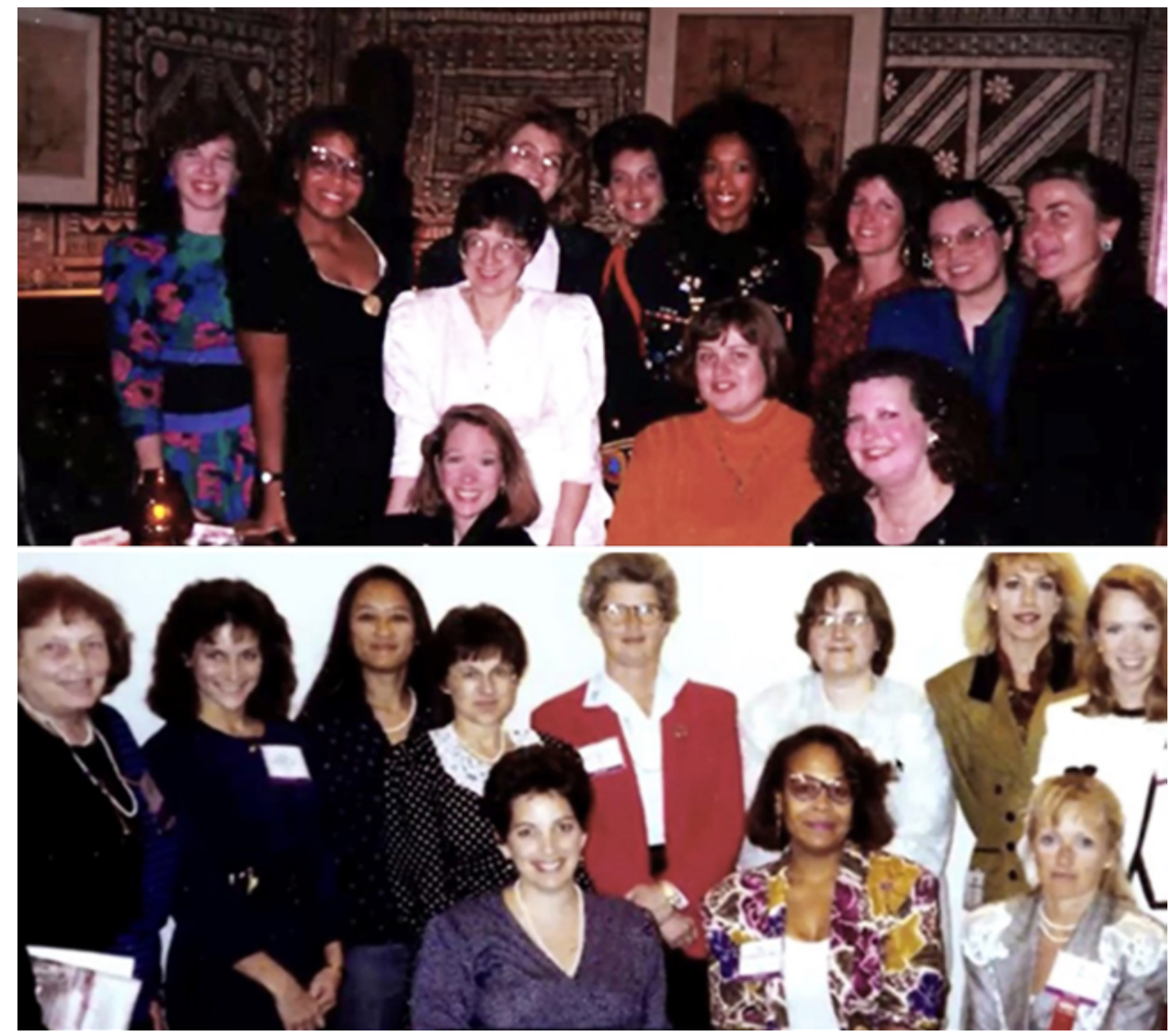

FIG. 1. Beginning and first years of WINS. Upper: Beginning of WINS at the CNS Annual Meeting in Atlanta, Georgia, 1989. Lower: First Year of WINS at the CNS Annual Meeting in Los Angeles, California, 1990, featuring WINS meeting attendees including Dr. Deborah Benzil (WINS founder and first president) and Dr. Gail Rosseau (WINS founder and president in 1994). Adapted from images featured in the WINS 30-year celebration video "Women in Neurosurgery," 2020 AANS Film Series. Shown at the WINS virtual cocktail party, "Celebrating 30 Years of WINS," October 22, 2020, in Boston, Massachusetts. Copyright Deborah L. Benzil. Published with permission.

From that meeting, it became clear that there was a need for an organized program to facilitate communication, establish networking, and create mentorship opportunities for women in neurosurgery and those aspiring to become neurosurgeons. The first step toward achieving that goal was to organize in some fashion.

Organizing the first official meeting was done by hand, with dozens of handwritten invitations made and sent. This was the start of annual social events during national meetings that would provide opportunities for women to connect, share their experiences, identify barriers to career advancement, and develop collective solutions (Fig. 1). At the first meeting, a charter and bylaws were ratified, and the goals of the organization were established: 1) provide a network of communication among women neurosurgeons; 2) provide a resource for those women hoping to enter into training in neurosurgery or advance their careers within neurosurgery; 3 ) provide a forum for discussing issues relating to neurosurgery as they directly apply to women; and 4) provide a means of expressing views to the public, the larger neurosurgery community, or any other group pertaining to neurosurgical practice, residency training, delivery of medical care, or any other related matters deemed appropriate by the membership.
The founding members took on the burden of the administrative work and expenses. Many women were hesitant to join WINS at the time, fearing negative perceptions from their peers and further isolation within their departments. Many of the women that did join kept their membership a secret from their peers and departments. As such, the public existence of WINS was largely suppressed until 1994. That year, an unexpected official letter from the AANS was sent to all department chairs to raise awareness about WINS and encourage all female, as well as male, resident and staff involvement with the organization, a milestone in itself.

The leaders of WINS throughout this decade sought to advance its goals and make progress year after year. These leaders include Deborah L. Benzil, the first president of WINS in 1990, followed by Kym Chandler (1991), Karin Muraszko (1992), Isabelle Germano (1993), Gail Rosseau (1994), Diane Kraemer (1995), Lucy Love (1996), Anne Marie Flannery (1997), Emily Friedman (1998), and Daria Schooler (1999; Table 1). As the proportion of female residents in neurosurgery increased, WINS membership steadily rose as well. By the end of the first decade, women made up $10 \%$ of neurosurgery residents, with a promising upward trend for the coming years. ${ }^{4,9}$ The number of 
TABLE 1. WINS past presidents

\begin{tabular}{|c|c|}
\hline WINS President & Year \\
\hline Deborah Benzil, MD & 1990 \\
\hline Kym Chandler, MD & 1991 \\
\hline Karin Muraszko, MD & 1992 \\
\hline Isabelle Germano, MD & 1993 \\
\hline Gail Rosseau, MD & 1994 \\
\hline Diane L. Kraemer, MD & 1995 \\
\hline Lucy Love, MD & 1995-1996 \\
\hline Anne Marie Flannery, MD & 1997 \\
\hline Emily Friedman, MD & 1998 \\
\hline Daria Schooler, RPh, MD & 1999 \\
\hline Edie E. Zusman, MD & 2000 \\
\hline Sherry Apple, MD & 2001 \\
\hline Roxanne Todor, MD & 2001-2002 \\
\hline Denise Crute, MD & 2003 \\
\hline Holly S. Gilmer-Hill, MD & 2004 \\
\hline Kimberly A. Page, MD & 2005 \\
\hline Jaime S. Ullman, MD & 2006 \\
\hline Susan C. Pannullo, MD & 2007 \\
\hline Lauren Schwartz, MD & 2008 \\
\hline Aviva Abosch, MD, PhD & 2009 \\
\hline Shelly D. Timmons, MD, PhD & 2010 \\
\hline Odette Harris, MD, MPH & 2011 \\
\hline Eve Tsai, MD, PhD & 2012 \\
\hline Julie G. Pilitsis, MD, PhD & 2013 \\
\hline Aruna Ganju, MD & 2014 \\
\hline Uzma Samadani, MD, PhD & 2015 \\
\hline Stacey C. Wolfe, MD & 2016 \\
\hline Ann M. Parr, MD, PhD & 2017 \\
\hline Jennifer Sweet, MD & 2018-2019 \\
\hline
\end{tabular}

board-certified female neurosurgeons tripled to 72 , and the female neurosurgical resident attrition rate was reduced from $25 \%$ to $17 \% .{ }^{6}$ While tremendous work and the creation of a solid foundation was already accomplished by WINS at this juncture, the initial goals upon which the group was founded remained the primary focus over the next decade. Accomplishments during these years included official incorporation, establishment of a newsletter, and initiation of lecture programs and a scholarship.

The 3 remarkable women who founded WINS became visionary role models for those around them. Deborah Benzil, the first president of WINS, became a leader in resident education, socioeconomics in neurosurgery, and spine stereotactic radiosurgery, and the first female chair of the Council of State Neurological Societies (CSNS). Karin Muraszko became a leader in pediatric neurosurgery and the first female neurosurgical department chair (a position she currently holds), as well as the first female member of the American Board of Neurological Surgery (ABNS), Residency Review Committee, and president of the SNS. Gail Rosseau became the first women elected to the AANS board and the first female neurosurgeon officer of the AANS, and she is internationally recognized for her skull base expertise and contribution to neurosurgery in underdeveloped countries. These women inspired many others to join in making tremendous contributions to the field.

\section{Second Decade of WINS}

The WINS organization continued to thrive during 2000-2009. This part of its history began with Edie E. Zusman, MD, serving as president. Successive presidents included Drs. Sherry Apple (2001), D. Roxanne Todor (2001-2002), Denise Crute (2003), Holly S. Gilmer-Hill (2004), Kimberly A. Page (2005), Jaime S. Ullman (2006), Susan C. Pannullo (2007), Lauren Schwartz (2008), and Aviva Abosch (2009; Table 1). ${ }^{10}$ During this time, WINS achieved greater integration within organized neurosurgery, securing critical liaison positions. These positions included Gail Rosseau being appointed to the AANS Scientific Program Committee and Karin Muraszko assuming the WINS liaison position at the AANS. ${ }^{11}$ Notable growth of the organization included a membership increase, enhanced international outreach, strategic integration with other neurosurgical organizations, and consolidation of the value of the awards and lecture programs.

To honor their 10th anniversary, WINS created the brochure "So, You Want To Be A Neurosurgeon?" compiled by Karin Muraszko and Deborah Benzil and designed to promote diversity. The brochure included a cover featuring a female neurosurgeon operating under a microscope (Fig. $2)^{10}$ and received endorsements from the AANS/CNS and was made available to all medical schools in the country for interested students. Subsequent versions became digital and posted online. In 2001, WINS celebrated several events: 1) hosting Lynn Martin, former secretary of labor and congresswoman, as the 8th Annual Ruth Kerr Jakoby Lecturer at the AANS Annual Meeting in Toronto, Canada; 2) bestowing the Friends of WINS Award to Franklin C. Wagner Jr., MD, for his notable efforts in training women to become neurosurgeons; ${ }^{11,12}$ and 3) making the Louise Eisenhardt Resident Travel Scholarship a recurring award granted to an outstanding resident abstract accepted at the AANS Annual Meeting (Table 2). ${ }^{13}$

Amid the joys and successes of 2000-2001, there came great sorrow. In July 2001, Dr. Sherry Apple was tragically killed in a boating accident near upstate New York..$^{14}$ At 49 years old, she achieved great accomplishments in her career. In addition to being current president of WINS, she was "one of only four brain surgeons in the Kanawha Valley and the only female neurosurgeon in the state [of West Virginia]."14 Dr. Apple "was enamored with new and creative surgical procedures that would reduce pain and heal," and she debuted stereotactic radiosurgery and balloon vertebroplasty in the area. ${ }^{14}$ "She was known for her trademark apple bandages as well as her empathy and professionalism."13 A WINS-sponsored luncheon in memory of Dr. Apple was held at the 2002 AANS Annual Meeting in Chicago, Illinois. ${ }^{13}$ Dr. Apple's death continues to be a loss to WINS and the neurosurgical community.

As of April 2003, WINS had 215 members worldwide, $28.8 \%$ resident members, $3.3 \%$ lifetime members, and $3.3 \%$ 5-year members..$^{15}$ As a testament of WINS' global 


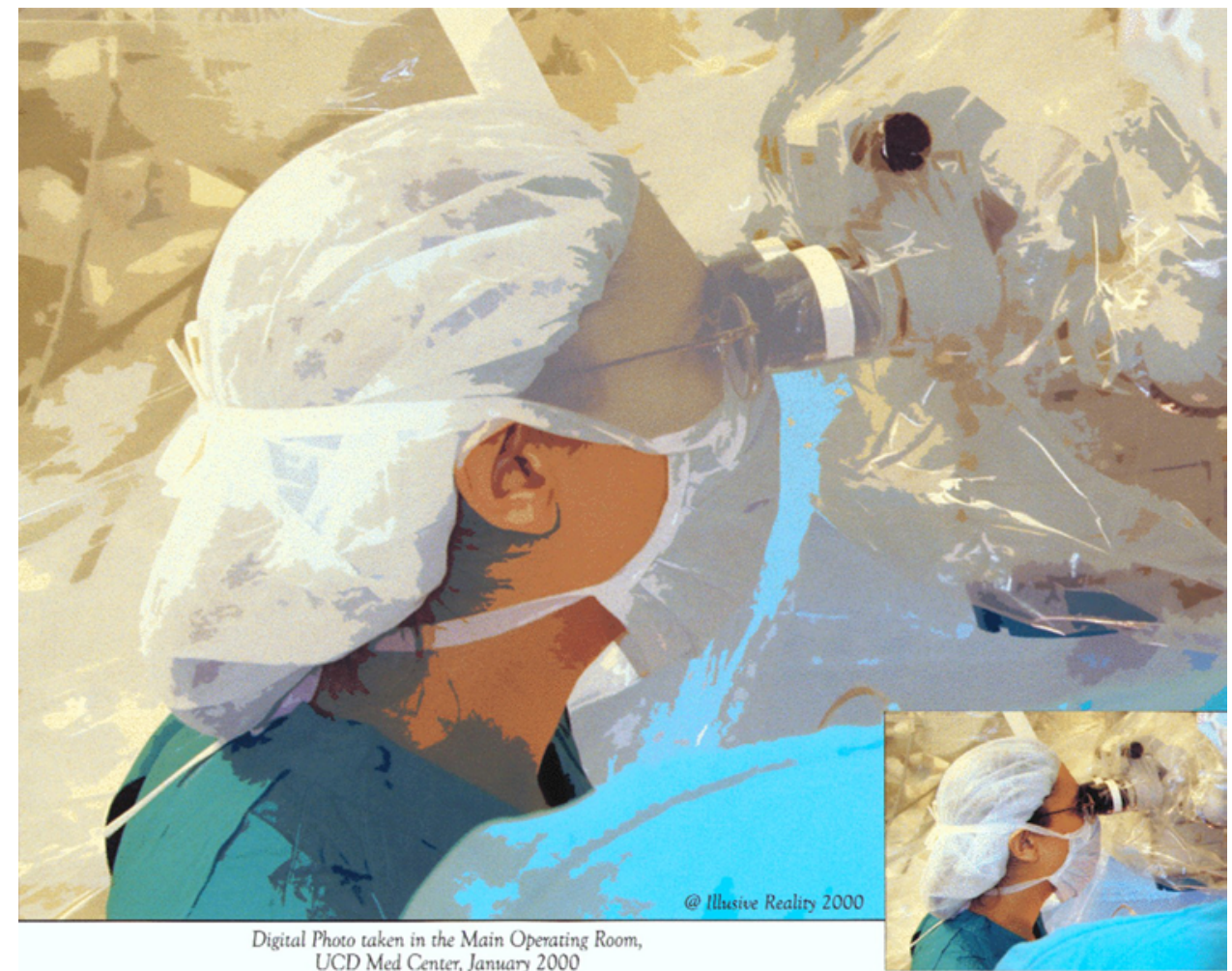

FIG. 2. Cover artwork for the brochure "So, You Want To Be A Neurosurgeon?" compiled by WINS to honor its 10th anniversary, featuring a female neurosurgeon operating under a microscope. No copyright reserved.

reach, several international colleagues were in attendance at a WINS reception at the 2003 AANS Annual Meeting in San Diego, California. ${ }^{15}$ Later that year, WINS hosted a practical course titled "Career Development for Women in Neurosurgery" at the CNS Annual Meeting in Denver, Colorado, to "teach effective strategies for enhancing motivation and setting goals for professional development and personal achievement." 15 This course embodied much of what is notable about WINS, a unique and innovative educational offering, the first of its type within neurosurgery, leading to similar courses routinely offered at future meetings. It also reflected WINS' early recognition of leadership development as the key to advancing women, and all of neurosurgery. Also at the meeting, Vickie Fal-

TABLE 2. WINS awards and awardees

\begin{tabular}{|c|c|c|}
\hline $\begin{array}{l}\text { Louise Eisenhardt Resident } \\
\text { Travel Scholarship Awardees }\end{array}$ & $\begin{array}{l}\text { Sherry Apple Resident Travel } \\
\text { Scholarship Awardees }\end{array}$ & $\begin{array}{l}\text { WINS/Greg Wilkins-Barrick Chair Visiting } \\
\text { International Surgeon Awardees }\end{array}$ \\
\hline $\begin{array}{l}2000 \text { Amy B. Heimburger, MD } \\
2001 \text { Eve Tsai, MD; Deepa Soni, MD } \\
2005 \text { Martina Stippler, MD } \\
2006 \text { Aymara Triana, MD } \\
2007 \text { Taryn M. Bragg, MD } \\
2008 \text { Bawarjan Schatlo, MD } \\
2009 \text { Jennifer A. Moliterno, MD } \\
2010 \text { Erin N. Kiehna, MD } \\
2011 \text { Amanda L. Muhs Saratsis, MD } \\
2012 \text { Amanda L. Muhs Saratsis, MD } \\
2013 \text { Scott Parker, MD } \\
2014 \text { Sophia F. Shakur, MD } \\
2015 \text { Teresa Purzner, MD } \\
2016 \text { Sophia F. Shakur, MD } \\
2017 \text { Jaclyn Janine Renfrow, MD } \\
2018 \text { Grace Yee Yan Lai, MD } \\
2019 \text { Laila Mohammad, MD }\end{array}$ & $\begin{array}{l}2006 \text { Simona Velicu, MD } \\
2007 \text { Jobyna H. Whiting, MD } \\
2008 \text { Michelle J. Clarke, MD } \\
2009 \text { Sameer A. Sheth, MD, PhD } \\
2010 \text { Nilesh Kurwale, MBBS } \\
2011 \text { Robert Partlow Naftel, MD } \\
2012 \text { Roy Dudley, MD } \\
2013 \text { Matthew Frank Gary, MD } \\
2014 \text { Franziska Loebel, MD } \\
2015 \text { Sophia F. Shakur, MD } \\
2016 \text { Noorulain lqbal, MD } \\
2017 \text { Derek W. Yecies, MD } \\
2018 \text { Charuta Furey, MD } \\
2019 \text { Courtney Pendleton, MD }\end{array}$ & $\begin{array}{l}2013 \text { Helen M. Fernandes, MD, FRCS, United } \\
\text { Kingdom; Claire Karekezi, MD, Morocco } \\
2014 \text { Abhidha Harshad Shah, MS, MD, India; } \\
\text { Mahjouba Boutarbouch, MD, Morocco } \\
2015 \text { Ling Feng, MD, PhD, China; Selfy Oswari, } \\
\text { MD, Indonesia } \\
\text { 2016, Marina Khachatryan, MD, Armenia; Lynne } \\
\text { Lourdes N. Lucena, MD, Philippines } \\
2017 \text { Soha Alomar, MD, Saudi Arabia; } \\
\text { Dhivya Palanisamy, MBBS, DNB, India } \\
2018 \text { Idoya Zazpe, MD, PhD, Spain } \\
2019 \text { Anke Höllig, MD, Germany; } \\
\text { Silvia Hernández Durán, MD, Germany }\end{array}$ \\
\hline
\end{tabular}




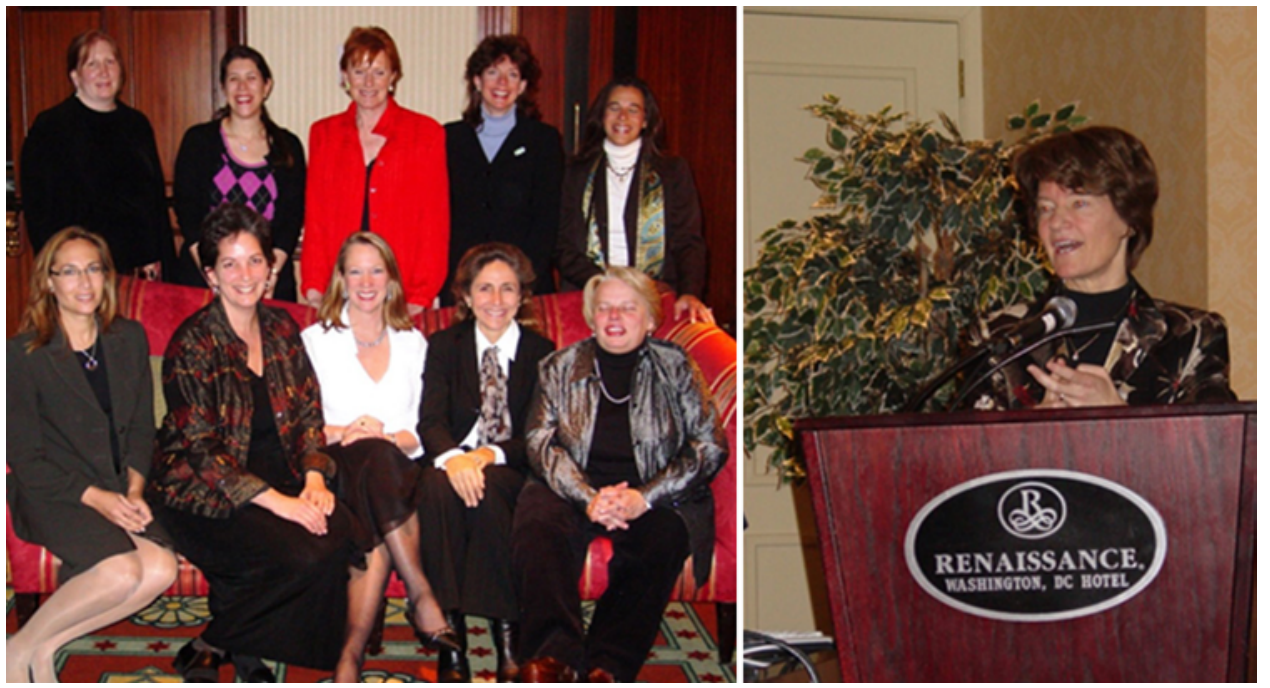

FIG. 3. WINS lecturers and guests throughout the years. Left: WINS members with Celia Sandys (center, back row), granddaughter of Sir Winston Churchill, at the CNS Annual Meeting in Chicago, Illinois, 2006. Right: Sally K. Ride, PhD, first US female astronaut, and the inaugural 2007 AANS Louise Eisenhardt Lecturer. Copyright Deborah Benzil. Published with permission.

cone, corporate and police trainer and author, who was the Alexa Canady Lecturer, discussed interactions and connections with patients and peers..$^{16}$

In 2004, WINS celebrated its 15th anniversary with a reception on October 19 at the 2004 CNS Annual Meeting in San Francisco, California. Martha Marsh, president and CEO of Stanford Hospital and Clinics, was the Alexa Canady Lecturer, speaking about the value of neurosurgeons in the clinical setting..$^{17}$ By its 15 -year anniversary, WINS had grown from 12 members in 1989 to 174 members globally, and $36.8 \%$ residents/fellows. ${ }^{17}$

As part of its commitment to mentorship, at the 2005 AANS Annual Meeting in New Orleans, Louisiana, WINS hosted a panel for the Ruth Kerr Jakoby Lecture with Drs. Alexa Canady, Ann-Christine (Tina) Duhaime, and Karin Muraszko discussing strategies for a fulfilling career in neurosurgery. ${ }^{18}$ In 2006, Drs. Sarah I. Woodrow, Holly S. Gilmer-Hill, and James T. Rutka published "The neurosurgical workforce in North America: a critical review of gender issues," which dissected gender disparities within neurosurgery, highlighting challenges women face including unique lifestyle concerns, limited mentorship, outdated career programs, and deep-seated societal beliefs, as well as issues of discrimination and harassment. ${ }^{8}$ The same year, Drs. Deborah Benzil and Edward von der Schmidt III published "Toward harnessing forces of change-assessing the neurosurgical workforce," ${ }^{19,20}$ highlighting the fact that, despite women comprising $55 \%$ of medical school acceptances, only $10 \%$ of entering neurosurgery resident positions were filled by women. Simona Velicu, MD, a first-year resident at Loyola University Chicago, became the first recipient of the Sherry Apple Resident Travel Scholarship on October 10, 2006, named in honor of the former WINS president who passed in 2001. ${ }^{21}$ The scholarship, granted yearly to an outstanding resident abstract presented at the CNS Annual Meeting, includes a stipend for travel expenses to the meeting (Table 2). ${ }^{21} \mathrm{On}$ October 12, 2006, WINS hosted its first sponsored plenary lecture at the CNS. This historic event at the CNS Annual Meeting in Chicago, Illinois, featured Celia Sandys, noted historian and granddaughter of Sir Winston Churchill, who presented on the topic of "The Inspiring Leadership of Winston Churchill: As Relevant Today as in World War II"20 (Fig. 3 left).

The year 2007 brought progress to WINS. Roxanne Todor led an initiative to update the WINS website, originally created by Sherry Apple, featuring WINS publications, biographical sketches of early women in the field, a medical student/resident corner with resources, and information on upcoming events..$^{20}$ She also coordinated the newly created WINS Mentoring Program, matching experienced WINS members with residents/medical students interested in neurosurgery. ${ }^{20}$ As stated by Dr. Kathryn Ko regarding women neurosurgical mentors: ${ }^{22,23}$

Inspire the women around you to join forces.... May we support one another because all women benefit in spite of only one or two moving ahead at a time. Find the courage to elevate women even if it means that they will surpass and be better than you. Then imagine your daughter poised on their shoulders as part of an unyielding feminine ladder and know that her life will be higher for it. And have the comfort that despite the 1000 nights, 18000 miles and a few sundry tears spent to get here, this woman would chance the journey again.

WINS expanded its membership eligibility, encouraging both men and women to join. ${ }^{12,20}$ The WINS International Outreach Program was also established, aimed at encouraging participation by women neurosurgeons throughout the world..$^{12}$ The 2007 recipient of the Friends of WINS Award was Donald O. Quest, MD, AANS president that year, who "tirelessly sought to identify and appoint qualified women to key leadership positions." ${ }^{20}$ At the 2007 AANS Annual Meeting in Washington, DC, he promoted the inaugural Louise Eisenhardt Lecture, held during a plenary session in honor of Louise Eisenhardt's tenure as president of the Harvey Cushing Society 70 years earlier. ${ }^{20}$ To commemorate this historic event at the 
TABLE 3. WINS Louise Eisenhardt Lecturers

\begin{tabular}{cl}
\hline Year & \\
\hline 2007 & Sally Ride, PhD, American astronaut \\
\hline 2008 & Marcia Angell, MD, Editor of New England Journal of Medicine \\
\hline 2009 & $\begin{array}{l}\text { Geraldine Brooks, Pulitzer Prize-winning author of People of } \\
\text { the Book, Nine Parts of Desire, March, and others }\end{array}$ \\
\hline 2010 & $\begin{array}{l}\text { Mary Sue Coleman, PhD, President of the University of } \\
\text { Michigan }\end{array}$ \\
\hline 2011 & Kristen Iversen, author of Molly Brown: Unraveling the Myth \\
\hline 2012 & $\begin{array}{l}\text { Cynthia Breazeal, ScD, Associate Professor of Media Arts } \\
\text { and Sciences at MIT, Director of the Personal Robots Group } \\
\text { at the MIT Media Laboratory }\end{array}$ \\
\hline 2013 & $\begin{array}{l}\text { Carolyn M. Clancy, MD, Director of the Agency for Healthcare } \\
\text { Research and Quality }\end{array}$ \\
\hline 2014 & $\begin{array}{l}\text { Anne Marie Slaughter, PhD, President and CEO of New } \\
\text { America Foundation }\end{array}$ \\
\hline 2015 & $\begin{array}{l}\text { Sally Satel, MD, practicing psychiatrist and author of multiple } \\
\text { publications }\end{array}$ \\
\hline 2016 & $\begin{array}{l}\text { Petra Kaufmann, MD, MSc, Director of the Office of Rare } \\
\text { Diseases Research and the Division of Clinical Innovation at } \\
\text { the National Center for Advancing Translational Sciences }\end{array}$ \\
\hline 2017 & $\begin{array}{l}\text { Amy Cuddy, PhD, social psychologist and Professor at Har- } \\
\text { vard Business School }\end{array}$ \\
\hline 2018 & $\begin{array}{l}\text { Angela Duckworth, Founder and CEO of Character Lab, } \\
\text { and author of the bestseller Grit: The Power of Passion and } \\
\text { Perseverance }\end{array}$ \\
\hline Fall for It...Every Time
\end{tabular}

MIT = Massachusetts Institute of Technology.

75th AANS Annual Meeting, Sally Kristen Ride, PhD, the first US woman to travel to space, delivered the address on April 17, 2007 (Fig. 3 right). ${ }^{20}$ On the morning of her lecture, WINS held a breakfast in her honor (Table 3). ${ }^{12}$ Lastly, on December 14, 2007, WINS held its first regional meeting and reception, with dinner in the Chelsea neighborhood of New York City. ${ }^{12}$ It included an interactive discussion titled "Achieving what you want in the workplace," facilitated by two management consultants. ${ }^{24}$

In 2008, WINS had 181 members globally. ${ }^{23}$ In September 2008, the monumental article "The future of neurosurgery: a white paper on the recruitment and retention of women in neurosurgery" 5 was published by WINS at the request of the Board of Directors of the AANS. This influential publication charted a strategic plan to overcome barriers for women in neurosurgery, including identifying and eliminating discriminatory practices in medical student recruitment, training of residents, and hiring and advancement of neurosurgeons. Also in 2008, WINS member survey results showed that $63.3 \%$ felt there was a glass ceiling for women in academic neurosurgery, and $64.3 \%$ for women in organized neurosurgery; $76.4 \%$ saw the need for a women's advocacy group, and $86.8 \%$ believed there was gender discrimination in neurosurgery. ${ }^{23}$ During this time, despite an increase in women residents accepted in neurosurgery, there was a disparity in the attrition of female residents (17\%) compared to their male counterparts (5.3\%), shedding light on the need for recruitment and retention of women in neurosurgery. ${ }^{27}$

To end its second decade of existence, WINS worked with the AANS to publish Heart of a Lion, Hands of a Woman: What Women Neurosurgeons Do, edited by Deborah Benzil and Karin Muraszko. ${ }^{25,26}$ The book received significant external notice, including a laudatory review in The Journal of the American Medical Association. This collection of personal essays and artwork "was undertaken as a celebration of the 20th anniversary of WINS and represent[ed] the memoirs, reflections, and personal expression of women who have shared similar struggles in their pursuit." ${ }^{26}$ The book, treasured by new residents, reached women outside medicine with similar struggles, including law and finance. Also in 2009, WINS hosted the Northeastern Regional Meeting in New York City, and the first annual Women in Spine Symposium (WISE) in December in Las Vegas, Nevada, featuring keynote speaker Dr. Debra Petrucci, a spine neurosurgeon and the first female graduate of the Massachusetts General Hospital neurosurgery residency program. ${ }^{26}$ Major milestones were achieved during the second decade of WINS. At that time, 11 women neurosurgeons obtained ABNS certification in $2004,,^{18} 12$ women in $2005,,^{28} 13$ in $2006,{ }^{20} 13$ in $2007,{ }^{24}$ and 19 in $2008-2009 .{ }^{23,26}$ The total number of board-certified US women neurosurgeons increased from 98 in $2001^{11}$ to 192 in $2008 .{ }^{23}$

\section{Third Decade to the Present}

The third decade of WINS continued the momentum of years prior, with yearly progress toward the fundamental mission of WINS, i.e., "To educate, inspire, and encourage women neurosurgeons to realize their professional and personal goals, and to serve neurosurgery in addressing the issues inherent to training and maintaining a diverse and balanced workforce." This decade followed the 2008 white paper calling for an increase in female representation in the field, establishing the goal of $20 \%$ female representation in training programs and neurosurgery faculty by $2020 .{ }^{5}$ During this time, women graduating medical school exceeded men for the first time in history, ${ }^{5}$ and there was palpable change in female representation in neurosurgical training programs. The leaders of WINS included Shelly Timmons (2010), Odette Harris (2011), Eve Tsai (2012), Julie Pilitsis (2013), Aruna Ganju (2014), Uzma Samadani (2015), Stacey Wolfe (2016), Ann Parr (2017), and Jennifer Sweet (2018-2019; Table 1).

In 2018, Renfrow et al. published the article "Tracking career paths of women in neurosurgery," which provided further insight into low numbers of female neurosurgeons in academic leadership positions. ${ }^{4}$ Despite this, female representation in neurosurgery made steady strides during this decade, as evidenced by increased leadership by women in organized and academic neurosurgery and highprofile recognition of their achievements. Karin Muraszko was appointed the first female chairperson of a neurosurgery department in 2005, although it took more than a decade for the second woman to achieve a similar position. As of 2020, there are now 4 women department chairs, including Drs. Linda Liau, Aviva Abosch, and Shelly Timmons 
Hdeib et al.
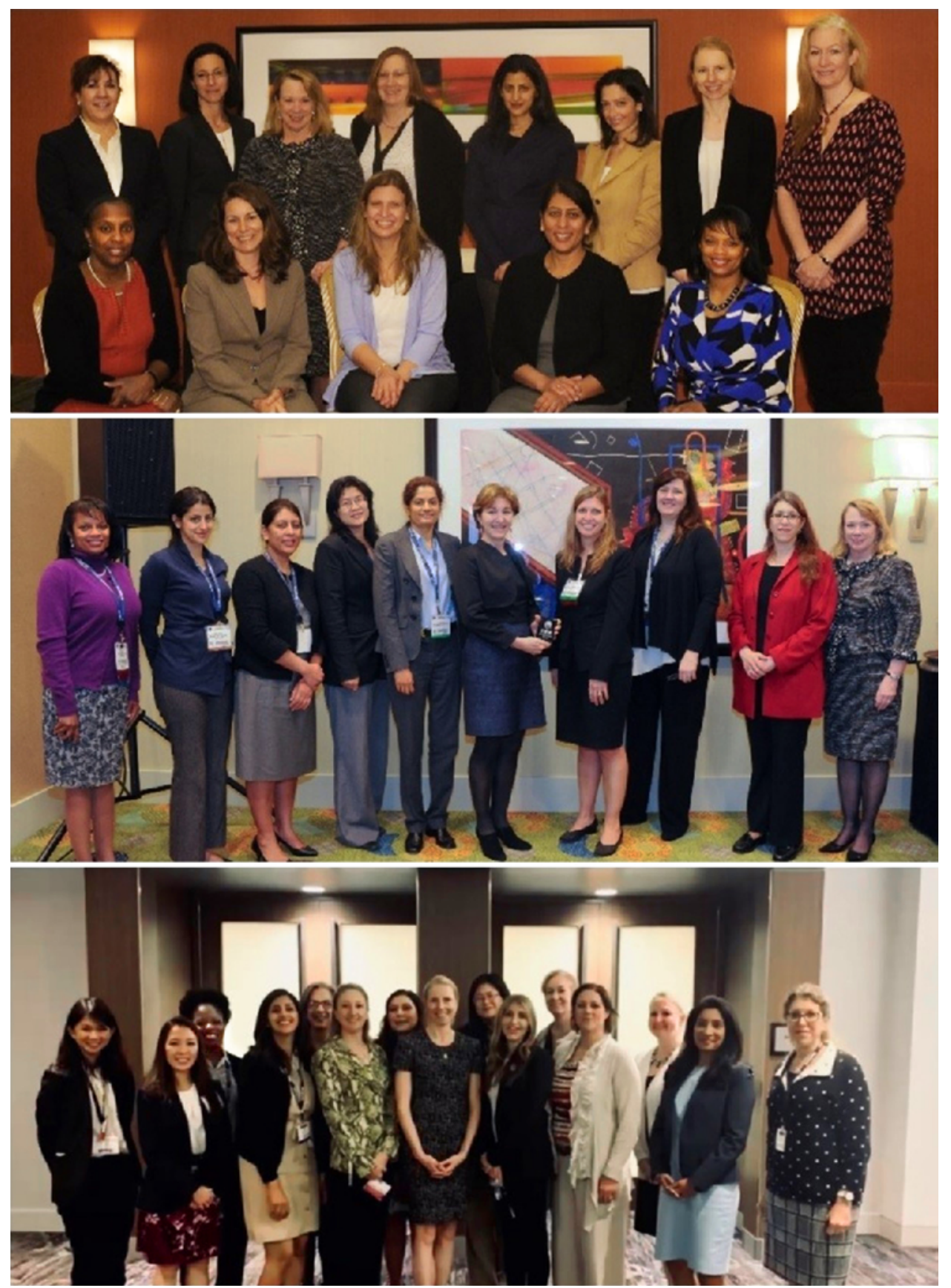

FIG. 4. WINS Executive Committee members and guests throughout the years. Adapted from images featured in the WINS 30 -year celebration video "Women in Neurosurgery," 2020 AANS Film Series. Shown at the WINS virtual cocktail party, "Celebrating 30 Years of WINS," October 22, 2020, in Boston, Massachusetts. Copyright AANS. Published with permission.

(Susan Durham served as chair at the University of Vermont until she accepted a pediatric leadership position in California). In 2014, Drs. Karin Muraszko and Shelly Timmons were awarded the "Inspirational Physician Award" by the American Medical Association for their dedication to the advancement of women in medicine. In 2018, Dr. Shelly Timmons became president of the AANS, the first woman elected to this prestigious position. Both Dr. Shelly Timmons and Dr. Ann Stroink became chairs of the Washington Committee, while Dr. Stroink also joined Dr. Benzil in the position of leadership (chair) of the CSNS.
A milestone for WINS and the neurosurgical community was the establishment of WINS as an AANS/CNS joint section. With approval of the AANS/CNS organizations, during the WINS chairmanship of Dr. Julie Pilitsis, WINS had the opportunity to become the AANS/CNS Section of Women in Neurosurgery. ${ }^{29}$ In 2013, the executive committees of both parent organizations ratified the petition for WINS section status, and in October 2014 at the CNS Annual Meeting in Boston, Massachusetts, WINS held its inaugural session. ${ }^{29}$ As noted in the section's newsletter, "This was a landmark moment for the organization; it 


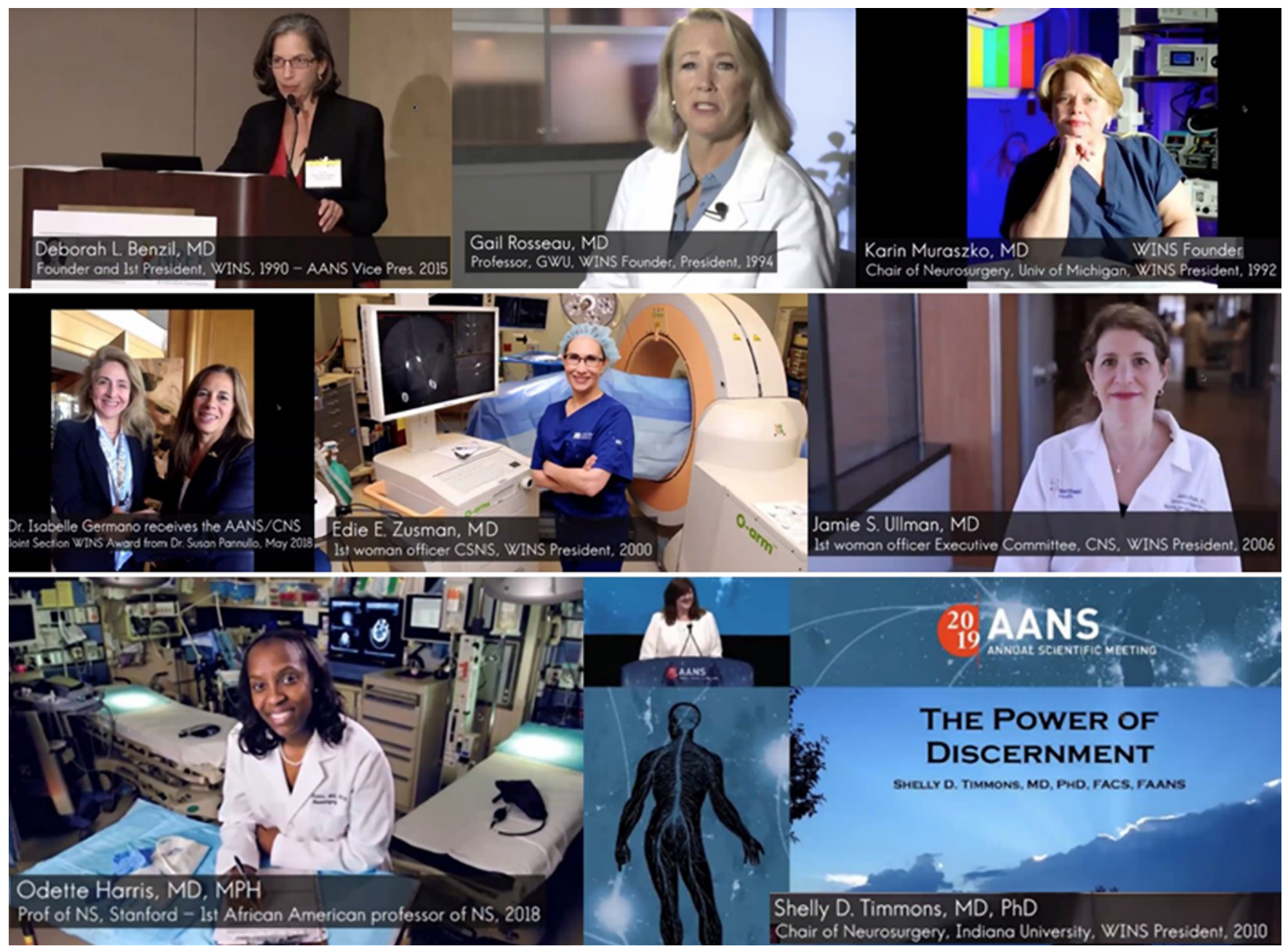

FIG. 5. WINS leaders throughout the years. Adapted from images featured in the WINS 30-year celebration video "Women in Neurosurgery," 2020 AANS Film Series. Shown at the WINS virtual cocktail party, "Celebrating 30 Years of WINS," October 22, 2020, in Boston, Massachusetts. Copyright AANS. Published with permission.

gives the section an equal seat at the table with the other neurosurgery subspecialties/subpopulations." ${ }^{29}$ In 2013, WINS also announced the establishment of the WINS/ Greg Wilkins-Barrick Chair Visiting International Surgeon Award, funding travel and registration for an international woman in neurosurgery to encourage collegiality, education, and collaboration (Table 2). ${ }^{30}$

Perhaps one of the greatest gains for women in neurosurgery in the past decade, due in part to increased leadership in organized and academic neurosurgery, has been a cultural shift in which the field values attracting the best and brightest students without consideration of an additional gender moniker. Furthermore, we became more open to discussing specific barriers, such as pregnancy and parental leave, among neurosurgeons ${ }^{31}$ and discovering ways to improve these barriers. As noted in the WINS 2016 newsletter, nearly half the joint section chairs and scientific program chairs for the AANS meetings and sections meetings in 2015-2016 were women. ${ }^{32}$ Since 2009 , there have been multiple symposiums, retreats, featured speakers, and events held for mentorship, education, and support of women in neurosurgery, such as the CNS Inter- national Female Think Tank, the WINS retreat, leadership courses, and mentorship events (Fig. 4).

\section{Celebrating 30 Years of WINS}

The year 2020 brought a milestone to the neurosurgical community and to the WINS AANS/CNS joint section, with its celebration of 30 years since the organization's inception. The WINS Executive Committee, led by president Dr. Martina Stippler, in 2020 set forth a program for celebrating the 30th anniversary of WINS. Unfortunately, the unprecedented COVID-19 pandemic and cancelation of in-person events necessitated WINS to turn to digital/ virtual means of celebrating, including a virtual celebration held over a digital/audiovisual platform on October 22,2020 , to premiere a video commissioned by WINS detailing the history of the organization as part of the celebration (Fig. 5). ${ }^{33}$ The event was attended by several of the WINS founders and past presidents, including Dr. Deborah Benzil, its first president, who spoke about the inception of the group, and ended with current and future initiatives under the guidance of Drs. Martina Stippler, 
WINS current president; Ellen Air, president-elect; Sarah Woodrow, secretary; and Sharona Ben-Haim, treasurer.

\section{Conclusions}

WINS has grown, thriving for three decades. Progress was slow but steady, reaping the benefits of the foundation laid by the founding members. The changes realized helped all of neurosurgery-not just its women-to improve in many ways. The organization will continue to work to recruit and retain the best and brightest to this rewarding specialty and help ensure an optimal environment for career longevity and satisfaction.

\section{References}

1. Tomei KL, Nahass MM, Husain Q, et al. A gender-based comparison of academic rank and scholarly productivity in academic neurological surgery. J Clin Neurosci. 2014;21(7): 1102-1105.

2. Spetzler RF. Progress of women in neurosurgery. Asian J Neurosurg. 2011;6(1):6-12.

3. Sweet JA, Holanda VM, Rao G, et al. Letter: Congress of Neurological Surgeons Female International Think Tank Report: much progress, still work to be done. Neurosurgery. 2019;85(3):E599-E606.

4. Renfrow JJ, Rodriguez A, Wilson TA, et al. Tracking career paths of women in neurosurgery. Neurosurgery. 2018;82(4): 576-582.

5. Benzil DL, Abosch A, Germano I, et al. The future of neurosurgery: a white paper on the recruitment and retention of women in neurosurgery. J Neurosurg. 2008;109(3):378-386.

6. Abosch A, Rutka JT. Women in neurosurgery: inequality redux. J Neurosurg. 2018;129(2):277-281.

7. Corley J, Williamson T. Women in neurosurgery: final frontier of career women's movement. World Neurosurg. 2018; 111:130-131.

8. Woodrow SI, Gilmer-Hill H, Rutka JT. The neurosurgical workforce in North America: a critical review of gender issues. Neurosurgery. 2006;59(4):749-758.

9. Bean J. Women in neurosurgery. J Neurosurg. 2008;109(3): 377.

10. Women in Neurosurgery (WINS). Accessed January 20, 2021. http://www.neurosurgerywins.org

11. WINS Newsletter. Spring 2001. Accessed January 20, 2021. http://www.neurosurgerywins.org/wp-content/ uploads/2017/05/wins_spring2001.pdf

12. WINS Newsletter. Fall 2007. Accessed January 20, 2021. http://www.neurosurgerywins.org/wp-content/ uploads/2017/05/wins_fall2007.pdf

13. WINS Newsletter. Fall 2001. Accessed January 20, 2021. http://www.neurosurgerywins.org/wp-content/ uploads/2017/05/wins_fall2001.pdf

14. Remembering Sherry Apple MD. AANS Neurosurgeon. Published January 1, 2001. Accessed January 20, 2021. http://dev. aansneurosurgeon.org/remembering-sherry-apple-md/

15. WINS Newsletter. Fall 2003. Accessed January 20 2021. http://www.neurosurgerywins.org/wp-content/ uploads/2017/05/wins_fall2003.pdf

16. WINS Newsletter. Spring 2004. Accessed January 20 , 2021. http://www.neurosurgerywins.org/wp-content/ uploads/2017/05/wins_spring2004.pdf

17. WINS Newsletter. Fall 2004. Accessed January 20, 2021. http://www.neurosurgerywins.org/wp-content/ uploads/2017/05/wins_fall2004.pdf

18. WINS Newsletter. Spring 2005. Accessed January 20, 2021. http://www.neurosurgerywins.org/wp-content/ uploads/2017/05/wins_spring2005.pdf
19. Toward harnessing forces of change-assessing the neurosurgical workforce. AANS Neurosurgeon. Published January 1, 2006. Accessed January 20, 2021. http://dev.aansneurosurgeon.org/toward-harnessing-forces-of-change-assessing-theneurosurgical-workforce/

20. WINS Newsletter. Spring 2007. Accessed January 20, 2021. http://www.neurosurgerywins.org/wp-content/ uploads/2017/05/wins_spring2007.pdf

21. WINS Newsletter. Fall 2006. Accessed January 20, 2021. http://www.neurosurgerywins.org/wp-content/ uploads/2017/05/wins_fall2006.pdf

22. Ko K. The Survival Bible for Women in Medicine. The Parthenon Publishing Group, Inc; 1998.

23. WINS Newsletter. Fall 2008. Accessed January 2, 2021. http: //www.neurosurgerywins.org/wp-content/uploads/2017/05/ wins_fall2008.pdf

24. WINS Newsletter. Spring 2008. Accessed January 20, 2021. http://www.neurosurgerywins.org/wp-content/ uploads/2017/05/wins_spring2008.pdf

25. Benzil DL, Muraszko KM. Heart of a Lion, Hands of a Woman: What Women Neurosurgeons Do. American Association of Neurological Surgeons; 2009.

26. WINS Newsletter. Spring 2010. Accessed January 20, 2021. http://www.neurosurgerywins.org/wp-content/ uploads/2017/05/wins_spring2010.pdf

27. Renfrow JJ, Rodriguez A, Liu A, et al. Positive trends in neurosurgery enrollment and attrition: analysis of the 20002009 female neurosurgery resident cohort. J Neurosurg. 2016;124(3):834-839.

28. WINS Newsletter. Spring 2006. Accessed January 20, 2021. http://www.neurosurgerywins.org/wp-content/ uploads/2017/05/wins_spring2006.pdf

29. WINS Newsletter. Spring 2015. Accessed January 20, 2021. http://www.neurosurgerywins.org/wp-content/ uploads/2017/05/wins_spring2015.pdf

30. WINS Newsletter. Spring 2013. Accessed January 20, 2021. http://www.neurosurgerywins.org/wp-content/ uploads/2017/05//wins_spring2013.pdf

31. Gupta M, Reichl A, Diaz-Aguilar LD, et al. Pregnancy and parental leave among neurosurgeons and neurosurgical trainees. J Neurosurg. Published online May 29, 2020. doi: 10.3171/2020.2.JNS193345

32. WINS Newsletter. Spring 2016. Accessed January 20, 2021. http://www.neurosurgerywins.org/wp-content/ uploads/2017/05/wins_spring2016.pdf

33. WINS 30 Year Celebration Video. 2020 AANS Film Series. Video presentation at: WINS Virtual Cocktail Party: Celebrating 30 Years of WINS; October 22, 2020; Boston, MA.

\section{Disclosures}

The authors report no conflict of interest concerning the materials or methods used in this study or the findings specified in this paper.

\section{Author Contributions}

Conception and design: Hdeib, Benzil. Acquisition of data: Hdeib, Benzil. Analysis and interpretation of data: Hdeib, Benzil. Drafting the article: all authors. Critically revising the article: Hdeib, Ben-Heim, Benzil. Reviewed submitted version of manuscript: Hdeib, Benzil. Approved the final version of the manuscript on behalf of all authors: Hdeib. Study supervision: Hdeib, Benzil.

\section{Correspondence}

Alia Hdeib: University Hospitals, Case Western Reserve University, Cleveland, OH. alia.hdeib@uhhospitals.org. 